\title{
Multielemental Elution Behavior of Metal Ions Adsorbed on Iminodiacetic Acid Chelating Resin by Using Hydrogen Peroxide as an Eluent
}

\author{
Tomoki Yabutani, ${ }^{* \dagger}$ Hidehiko Sumi, ${ }^{* *}$ Takamasa Nakamura, ${ }^{* *}$ Shinsuke AKatsuki, ${ }^{* *}$ and \\ Le Thi Xuan ThuY**
}

*Department of Life System, Institute of Technology and Science, The University of Tokushima, 2-1 Minamijosanjima, Tokushima 770-8506, Japan

**Department of Earth and Life Environmental Engineering, Graduate School of Advanced Technology and

Science, The University of Tokushima, 2-1 Minamijosanjima, Tokushima 770-8506, Japan

\begin{abstract}
In the present work, we investigated the multielemental elution behavior of metal ions absorbed on iminodiacetic acid (IDA) chelating resin by using hydrogen peroxide $\left(\mathrm{H}_{2} \mathrm{O}_{2}\right)$ as an eluent. As a result, $\mathrm{V}(\mathrm{V}), \mathrm{Mo}(\mathrm{VI}), \mathrm{W}(\mathrm{VI}), \mathrm{Nb}(\mathrm{V})$ and $\mathrm{Ta}(\mathrm{V})$ were efficiently eluted by $\mathrm{H}_{2} \mathrm{O}_{2}$. In contrast, other metal ions were rarely recovered. The oxidation states of $\mathrm{V}(\mathrm{V})$, $\mathrm{Mo}(\mathrm{VI})$, and $\mathrm{W}(\mathrm{VI})$ were not changed through the $\mathrm{H}_{2} \mathrm{O}_{2}$ eluting process, checked by X-ray photoelectron analysis. In addition, the UV-vis adsorption spectra and IR spectra of $\mathrm{V}(\mathrm{V}), \mathrm{Mo}(\mathrm{VI})$ and $\mathrm{W}(\mathrm{VI})$ in the $\mathrm{H}_{2} \mathrm{O}_{2}$ eluent suggested the formation of metal-peroxo complexes through $\mathrm{H}_{2} \mathrm{O}_{2}$ elution. The desorption of these metal ions from IDA functional groups is explained in term of destabilization along with the coordination of peroxo-ligands to the $\mathrm{V}(\mathrm{V})-$, $\mathrm{Mo}(\mathrm{VI})-\mathrm{and}$ $\mathrm{W}(\mathrm{VI})-\mathrm{IDA}$ complexes, and a decrease in the adsorption capacity by electrostatic repulsion between dissociated carboxylic groups of IDA and the oxoanions in the neutral $\mathrm{pH}$ shown in $30 \mathrm{wt} \% \mathrm{H}_{2} \mathrm{O}_{2}$. When this method was applied to the selective separation of $\mathrm{V}(\mathrm{V}), \mathrm{Mo}(\mathrm{VI})$ and $\mathrm{W}(\mathrm{VI})$ from other metals in an acid soluble fraction of fly-ash, $83.4 \pm 2.5 \%$ of $\mathrm{V}(\mathrm{V}), 88.1 \pm 3.3 \%$ of $\mathrm{Mo}(\mathrm{VI})$, and $69.3 \pm 5.4 \%$ of $\mathrm{W}(\mathrm{VI})$ were recovered in a $30 \mathrm{wt} \% \mathrm{H}_{2} \mathrm{O}_{2}$ eluent.
\end{abstract}

(Received January 25, 2012; Accepted March 16, 2012; Published May 10, 2012)

\section{Introduction}

Iminodiacetic acid chelating resin (IDA resin) is a most widely and commercially available chelating resin utilized for the separation and pretreatment of multivalent metal ions. For example, the removal of interferential matrixes prior to instrumental analysis and waste managements, such as precious-metal recycling and hazardous-metal eliminating, was performed. ${ }^{1-4}$ In general, metal ions adsorbed on chelating resin are eluted by using strong acids, such as $\mathrm{HNO}_{3}, \mathrm{HCl}$, and $\mathrm{H}_{2} \mathrm{SO}_{4}$, in order to completely elute adsorbed metal ions from the resin. The elution of metal ions by using strong acids is achieved by exchange between metal ion and proton on the chelating functional groups. ${ }^{5}$ However, strong acids are not desirable solvents for the selective elution of adsorbed metal ions on the chelating resin. ${ }^{6}$

The present work was dealt with the elution of metal ions from IDA resin by using hydrogen peroxide $\left(\mathrm{H}_{2} \mathrm{O}_{2}\right)$ as an eluent $\mathrm{H}_{2} \mathrm{O}_{2}$ is a common reagent, and is widely used as redox reactive, decomposition, and titration reagents in chemical fields. Recently, the utilization of $\mathrm{H}_{2} \mathrm{O}_{2}$ is progressing in the "green" synthesis and selective oxidation of hydrocarbons. ${ }^{7,8}$ In fact, $\mathrm{H}_{2} \mathrm{O}_{2}$ can be recognized as an environmentally-friendly reagent, because it is a simple structural reagent consisting of only

† To whom correspondence should be addressed.

E-mail: yabutani@chem.tokushima-u.ac.jp hydrogen and oxygen atoms, and is easily decomposed to $\mathrm{H}_{2} \mathrm{O}$ and $\mathrm{O}_{2}$ by heat, light and catalysis. Therefore, $\mathrm{H}_{2} \mathrm{O}_{2}$ is considered to be a suitable solvent in the view of its purification of metals in the recycling process.

In this work, the multielemental elution behavior of over 25 kinds of metals adsorbed on IDA resin by using $\mathrm{H}_{2} \mathrm{O}_{2}$ as an eluent was investigated. This is the first attempt to characterize the elution behavior of metal ions from IDA resin by $\mathrm{H}_{2} \mathrm{O}_{2}$. Furthermore, this technique was applied to the separation of metals from an acid-soluble fraction of a fly-ash sample.

\section{Experimental}

\section{Instruments and reagents}

Shimadzu ICPM 8500 with quadrupole mass filter and a glass concentric nebulizer (flow rate, $500 \mu 1 \mathrm{~min}^{-1}$; Glass Expansion, USA) was mainly used for metallic analysis. The major elements $(\mathrm{Na}, \mathrm{Ca}, \mathrm{Mg}, \mathrm{Fe}, \mathrm{Al}, \mathrm{Zn}, \mathrm{Mn}, \mathrm{Pb}$, and $\mathrm{Cu})$ in the fly-ash sample were analyzed by ICP-AES (OPTIMA 3000, Perkin Elmer, Massachusetts, USA). The purified water used throughout the present experiment was prepared by a Milli-Q system (Millipore Gradient, Millipore, Tokyo, Japan). Multielement-containing solutions for recovery tests were prepared by mixing the single-element standard solutions listed in Table 1. According to a material data sheet of the standard solution for $\mathrm{V}$ from the manufacturer, it was prepared by dissolving metal $\mathrm{V}$ in a mixture of $\mathrm{HNO}_{3}$ and $\mathrm{HCl}$ solutions. 
Table 1 Standard solutions used for the recovery test together with the measured mass number $(\mathrm{m} / \mathrm{z})$ for ICP-MS or wavelength for ICP-AES

\begin{tabular}{|c|c|c|c|c|}
\hline Element & $\begin{array}{c}m / z \text { or } \\
\text { wavelength }\end{array}$ & Species $^{\mathrm{a}}$ & Solvent ${ }^{\mathrm{a}}$ & $\begin{array}{l}\text { Manu- } \\
\text { facturer }^{\mathrm{a}}\end{array}$ \\
\hline $\mathrm{Al}(\mathrm{III})$ & 308.215 & $\mathrm{Al}\left(\mathrm{NO}_{3}\right)_{3}$ & $0.2 \mathrm{~mol} \mathrm{dm}^{-3} \mathrm{HNO}_{3}$ & Kanto \\
\hline $\mathrm{Ba}(\mathrm{II})$ & 137 & $\mathrm{Ba}\left(\mathrm{NO}_{3}\right)_{2}$ & $0.5 \mathrm{~mol} \mathrm{dm}^{-3} \mathrm{HNO}_{3}$ & Kanto \\
\hline $\mathrm{Bi}(\mathrm{III})$ & 209 & $\mathrm{Bi}\left(\mathrm{NO}_{3}\right)_{3}$ & $0.5 \mathrm{~mol} \mathrm{dm}^{-3} \mathrm{HNO}_{3}$ & Wako \\
\hline $\mathrm{Ca}(\mathrm{II})$ & 393.366 & $\mathrm{CaCO}_{3}$ & $0.1 \mathrm{~mol} \mathrm{dm}^{-3} \mathrm{HNO}_{3}$ & Kanto \\
\hline $\mathrm{Cd}(\mathrm{II})$ & 111 & $\mathrm{Cd}\left(\mathrm{NO}_{3}\right)_{2}$ & $0.1 \mathrm{~mol} \mathrm{dm}^{-3} \mathrm{HNO}_{3}$ & Kanto \\
\hline $\mathrm{Ce}(\mathrm{III})$ & 140 & $\mathrm{Ce}\left(\mathrm{NO}_{3}\right)_{3}$ & $1 \mathrm{~mol} \mathrm{dm}^{-3} \mathrm{HNO}_{3}$ & Kanto \\
\hline $\mathrm{Co}(\mathrm{III})$ & 59 & $\mathrm{Co}\left(\mathrm{NO}_{3}\right)_{3}$ & $0.1 \mathrm{~mol} \mathrm{dm}^{-3} \mathrm{HNO}_{3}$ & Kanto \\
\hline $\mathrm{Cu}(\mathrm{II})$ & $\begin{array}{l}63 \text { or } \\
324.754\end{array}$ & $\mathrm{Cu}\left(\mathrm{NO}_{3}\right)_{2}$ & $0.1 \mathrm{~mol} \mathrm{dm}^{-3} \mathrm{HNO}_{3}$ & Kanto \\
\hline Dy(III) & 164 & $\mathrm{Dy}\left(\mathrm{NO}_{3}\right)_{3}$ & $1 \mathrm{~mol} \mathrm{dm}^{-3} \mathrm{HNO}_{3}$ & Wako \\
\hline $\operatorname{Er}(\mathrm{III})$ & 166 & $\mathrm{Er}_{2} \mathrm{O}_{3}$ & $1 \mathrm{~mol} \mathrm{dm}^{-3} \mathrm{HCl}$ & Kanto \\
\hline $\mathrm{Eu}(\mathrm{III})$ & 153 & $\mathrm{Eu}\left(\mathrm{NO}_{3}\right)_{3}$ & $1 \mathrm{~mol} \mathrm{dm}^{-3} \mathrm{HNO}_{3}$ & Wako \\
\hline $\mathrm{Fe}(\mathrm{III})$ & 259.940 & $\mathrm{Fe}\left(\mathrm{NO}_{3}\right)_{3}$ & $0.1 \mathrm{~mol} \mathrm{dm}^{-3} \mathrm{HNO}_{3}$ & Wako \\
\hline $\mathrm{Ga}(\mathrm{III})$ & 69 & $\mathrm{Ga}\left(\mathrm{NO}_{3}\right)_{3}$ & $1 \mathrm{~mol} \mathrm{dm}^{-3} \mathrm{HNO}_{3}$ & Kanto \\
\hline Hf(IV) & 178 & $\mathrm{HfF}_{4}$ & HF $5 \%$ & ACROS \\
\hline In(III) & 115 & $\mathrm{In}\left(\mathrm{NO}_{3}\right)_{3}$ & $0.2 \mathrm{~mol} \mathrm{dm}^{-3} \mathrm{HNO}_{3}$ & Kanto \\
\hline $\mathrm{La}(\mathrm{III})$ & 139 & $\mathrm{La}\left(\mathrm{NO}_{3}\right)_{3}$ & $1 \mathrm{~mol} \mathrm{dm}^{-3} \mathrm{HNO}_{3}$ & Wako \\
\hline $\operatorname{Mg}($ II $)$ & 279.079 & $\mathrm{Mg}\left(\mathrm{NO}_{3}\right)_{2}$ & $0.1 \mathrm{~mol} \mathrm{dm}^{-3} \mathrm{HNO}_{3}$ & Wako \\
\hline $\operatorname{Mn}(\mathrm{II})$ & $\begin{array}{l}55 \text { or } \\
257.610\end{array}$ & $\mathrm{Mn}\left(\mathrm{NO}_{3}\right)_{2}$ & $0.1 \mathrm{~mol} \mathrm{dm}^{-3} \mathrm{HNO}_{3}$ & Kanto \\
\hline $\mathrm{Mo}(\mathrm{VI})$ & 98 & $\mathrm{MoO}_{3}$ & $\begin{array}{l}0.4 \mathrm{~mol} \mathrm{dm}^{-3} \mathrm{HCl} \\
0.2 \mathrm{~mol} \mathrm{dm}^{-3} \mathrm{HNO}_{3}\end{array}$ & Kanto \\
\hline $\mathrm{Na}(\mathrm{I})$ & 588.995 & $\mathrm{NaCl}$ & Water & Kanto \\
\hline $\mathrm{Nb}(\mathrm{V})$ & 93 & $\mathrm{NbF}_{5}$ & $\mathrm{HF} 2 \%$ & Kanto \\
\hline $\mathrm{Nd}(\mathrm{III})$ & 142 & $\mathrm{Nd}\left(\mathrm{NO}_{3}\right)_{3}$ & $1 \mathrm{~mol} \mathrm{dm}^{-3} \mathrm{HNO}_{3}$ & Wako \\
\hline $\mathrm{Ni}(\mathrm{III})$ & 60 & $\mathrm{Ni}\left(\mathrm{NO}_{3}\right)_{3}$ & $0.1 \mathrm{~mol} \mathrm{dm}^{-3} \mathrm{HNO}_{3}$ & Kanto \\
\hline $\mathrm{Pb}(\mathrm{II})$ & $\begin{array}{l}208 \text { or } \\
220.353\end{array}$ & $\mathrm{~Pb}\left(\mathrm{NO}_{3}\right)_{2}$ & $0.1 \mathrm{~mol} \mathrm{dm}^{-3} \mathrm{HNO}_{3}$ & Kanto \\
\hline $\operatorname{Pr}(\mathrm{III})$ & 141 & $\operatorname{Pr}\left(\mathrm{NO}_{3}\right)_{3}$ & $1 \mathrm{~mol} \mathrm{dm}^{-3} \mathrm{HNO}_{3}$ & Wako \\
\hline $\operatorname{Re}(\mathrm{VII})$ & 185 & $\mathrm{NH}_{4} \mathrm{ReO}_{4}$ & Water & ACROS \\
\hline $\mathrm{Sm}(\mathrm{III})$ & 147 & $\mathrm{Sm}\left(\mathrm{NO}_{3}\right)_{3}$ & $1 \mathrm{~mol} \mathrm{dm}^{-3} \mathrm{HNO}_{3}$ & Wako \\
\hline $\operatorname{Sr}(\mathrm{II})$ & 88 & $\mathrm{SrCO}_{3}$ & $0.1 \mathrm{~mol} \mathrm{dm}^{-3} \mathrm{HNO}_{3}$ & Kanto \\
\hline $\mathrm{Ta}(\mathrm{V})$ & 181 & $\mathrm{TaF}_{5}$ & $\begin{array}{l}\mathrm{HF} 2 \% \text {, slight of } \\
\mathrm{HNO}_{3}\end{array}$ & Kanto \\
\hline $\mathrm{Tl}(\mathrm{I})$ & 205 & $\mathrm{TINO}_{3}$ & $0.5 \mathrm{~mol} \mathrm{dm}^{-3} \mathrm{HNO}_{3}$ & Kanto \\
\hline $\mathrm{V}(\mathrm{V})$ & 51 & $\mathrm{~V}^{\mathrm{b}}$ & $\begin{array}{l}0.2 \mathrm{~mol} \mathrm{dm}^{-3} \mathrm{HCl} \\
0.5 \mathrm{~mol} \mathrm{dm}^{-3} \mathrm{HNO}_{3}\end{array}$ & Wako \\
\hline $\mathrm{W}(\mathrm{VI})$ & 182 & $\mathrm{Na}_{2} \mathrm{WO}_{4}$ & Water & Kanto \\
\hline $\mathrm{Yb}(\mathrm{III})$ & 172 & $\mathrm{Yb}\left(\mathrm{NO}_{3}\right)_{3}$ & $1 \mathrm{~mol} \mathrm{dm}^{-3} \mathrm{HNO}_{3}$ & Kanto \\
\hline $\mathrm{Zn}(\mathrm{II})$ & $\begin{array}{l}66 \text { or } \\
213.586\end{array}$ & $\mathrm{Zn}\left(\mathrm{NO}_{3}\right)_{2}$ & $0.1 \mathrm{~mol} \mathrm{dm}^{-3} \mathrm{HNO}_{3}$ & Kanto \\
\hline $\mathrm{Zr}(\mathrm{IV})$ & 90 & $\mathrm{ZrO}\left(\mathrm{NO}_{3}\right)_{2}$ & $1 \mathrm{~mol} \mathrm{dm}^{-3} \mathrm{HNO}_{3}$ & Kanto \\
\hline
\end{tabular}

a. All of the standard solutions of these elements were analytical grade for atomic absorption spectrometry. The manufacturers of the standard solutions were Kanto Chemicals Co. Ltd., Wako Pure Chemical Industries, and ACROS Chemicals, respectively. The species were referred from the chemicals and the solvents labeled in the side of the bottle of the standard solution.

b. The standard solution was prepared by dissolving metal $\mathrm{V}$ in $0.2 \mathrm{~mol} \mathrm{dm}^{-3} \mathrm{HCl}, 0.5 \mathrm{~mol} \mathrm{dm}^{-3} \mathrm{HNO}_{3}$. The species of $\mathrm{V}(\mathrm{V})$ in the standard solution was estimated as $\mathrm{VO}_{2}{ }^{+}$by the reference. ${ }^{9}$

The species of $\mathrm{V}(\mathrm{V})$ in the standard solution was estimated to be mainly $\mathrm{VO}_{2}{ }^{+}$based on a reference. ${ }^{9}$ Infrared (IR) spectra and UV-visible (UV-vis) spectra were measured on an FTIR spectrometer (FT/IR-6200, JASCO Co. Ltd., Japan) and a UV-vis spectrometer (JASCO V-570 spectrometer, JASCO Co. Ltd., Japan), respectively. IDA resin (Muromac B-1; particle size, $0.3-1.3 \mathrm{~mm} ; \mathrm{Na}^{+}$form) was purchased from Muromachi Tecnos Inc. (Tokyo). The IDA resin was used after purification by loading $\mathrm{HCl}$ to the IDA resin. PTFE membrane filters (pore size, $0.45 \mu \mathrm{m})$ were also purchased from Nihon Millipore Kogyo (Tokyo, Japan).

\section{Elution of metal ions from the IDA resin}

The typical procedure of adsorption and elution was as follows. First, $1 \mathrm{~g}$ of a $100 \mathrm{mg} \mathrm{kg}^{-1}$ metal containing solution was added to $15 \mathrm{~g}$ of an acetate buffer solution. The $\mathrm{pH}$ of the sample was then adjusted to 5 . Next, after $1 \mathrm{~g}$ (dry weight) of the IDA resin was added into it, the solution was vigorously shaken for $2 \mathrm{~h}$ at $200 \mathrm{rpm}$. The IDA resin was separated by centrifugation at $3500 \mathrm{rpm}$ for $1 \mathrm{~min}$. The supernatant was removed by decantation, and the resin was washed with a few $\mathrm{ml}$ of pure water. The adsorbed metal ions on the IDA resin were eluted by $10 \mathrm{~g}$ of $\mathrm{a} \mathrm{H}_{2} \mathrm{O}_{2}$ aqueous solution. Then, $0.1 \mathrm{ml}$ of $1 \mathrm{mg} \mathrm{kg}^{-1} \mathrm{Ga}$, In, and Bi solution was added as internal standard elements for ICP-MS analysis.

In an XPS experiment to identify oxidation states of of $\mathrm{V}, \mathrm{Mo}$, and $\mathrm{W}$ in the $\mathrm{H}_{2} \mathrm{O}_{2}$ eluent, analytical samples were prepared by following scheme. One-hundred grams of an original solution (pH 5) containing $2.5 \mathrm{~g} \mathrm{~kg}^{-1}$ for $\mathrm{NH}_{4} \mathrm{VO}_{3}, 2.4 \mathrm{~g} \mathrm{~kg}^{-1}$ for $\left(\mathrm{NH}_{4}\right)_{6} \mathrm{Mo}_{7} \mathrm{O}_{24} \cdot 4 \mathrm{H}_{2} \mathrm{O}$, and $6.7 \mathrm{~g} \mathrm{~kg}^{-1}$ for $\mathrm{Na}_{2} \mathrm{WO}_{4}$ were firstly loaded on $10 \mathrm{~g}$ of IDA resin in order to adsorb $\mathrm{V}(\mathrm{V}), \mathrm{Mo}(\mathrm{VI})$, and $\mathrm{W}(\mathrm{VI})$ on the IDA resin. After washing the resin with pure water, $10 \mathrm{~g}$ of a $30 \mathrm{wt} \% \mathrm{H}_{2} \mathrm{O}_{2}$ solution was introduced to the $\mathrm{V}(\mathrm{V}), \mathrm{Mo}(\mathrm{VI})$, and $\mathrm{W}(\mathrm{VI})$ adsorbed IDA resin. The $\mathrm{H}_{2} \mathrm{O}_{2}$ eluent was evaporated so as to remove the solvent. After evaporating, the residues were analyzed by an XPS instrument (ESCA-1000, Shimadzu) to characterize the oxidation states.

Procedure of the recovery test used with an acid soluble fraction of metals in a fly-ash sample

An acid soluble fraction of a fly-ash sample was used for a recovery test in order to evaluate the practical applicability of the present method toward the selective separation of specific metals (V, Mo, and $\mathrm{W})$. The acid soluble fraction was obtained by the following scheme. The fly-ash of some municipal waste, which was collected at an incineration plant in Tokushima city, was homogenized with a mortar. Twenty grams of the ash were treated in $60 \mathrm{~g}$ of aqua regia at $100^{\circ} \mathrm{C}$ for $24 \mathrm{~h}$, and then at $180^{\circ} \mathrm{C}$ for $3 \mathrm{~h}$. The aqua regia was filtrated by using a $0.45-\mu \mathrm{m}$ pore-size membrane filter. The filtered solution was evaporated by the radiation of an infrared lamp in order to remove hydrochloric acid in the aqua regia soluble fraction. The reason why the hydrochloric acid was removed from the acid soluble fraction is that ${ }^{51} \mathrm{~V}$ as analytical isotope is severely interfered from ${ }^{35} \mathrm{Cl}^{16} \mathrm{O}$ in ICP-MS analysis determining original concentration in the acid soluble fraction. ${ }^{10}$ The residue was dissolved by $60 \mathrm{~g}$ of $2 \mathrm{M} \mathrm{HNO}_{3}$ with heating at $80^{\circ} \mathrm{C}$. The $2 \mathrm{M}$ $\mathrm{HNO}_{3}$ solution was filtered by a $0.45-\mu \mathrm{m}$ pore-size membrane filter. The filtrated sample was used as an acid soluble fraction for the recovery test. The original concentrations of $\mathrm{V}, \mathrm{Mo}$, and $\mathrm{W}$ in the acid soluble fraction were $\mathrm{V}, 11.6 \mathrm{mg} \mathrm{kg}^{-1}$; Mo, $5.83 \mathrm{mg} \mathrm{kg}^{-1}$; and $\mathrm{W}, 0.0873 \mathrm{mg} \mathrm{kg}^{-1}$, respectively. The recovery test was performed as follows. At first, $1.5 \mathrm{~g}$ of $100 \mathrm{mg} \mathrm{kg}^{-1}$ for $\mathrm{V}$ and $0.5 \mathrm{~g}$ of $100 \mathrm{mg} \mathrm{kg}^{-1}$ for Mo and $\mathrm{W}$ containing solution were spiked to $0.65 \mathrm{~g}$ of the acid soluble fraction to estimate their recoveries. Then, $28 \mathrm{~g}$ of ammonium acetate buffer solution $(\mathrm{pH} 4)$ and $6 \mathrm{~g}$ of IDA resin were added to the acid soluble fraction. The solution was vigorously shaken for $2 \mathrm{~h}$ at $200 \mathrm{rpm}$. The IDA resin was separated by centrifugation at $3500 \mathrm{rpm}$ for $1 \mathrm{~min}$. The supernatant was removed by decantation, and the resin was washed with a few $\mathrm{ml}$ of pure water. Then, $10 \mathrm{~g}$ of a $30 \mathrm{wt} \%$ of $\mathrm{H}_{2} \mathrm{O}_{2}$ solution was added into the IDA resin, and the solution was shaken. The $\mathrm{H}_{2} \mathrm{O}_{2}$ solution containing IDA resin was centrifuged at $3500 \mathrm{rpm}$ 
Table 2 Recoveries of metal ions adsorbed on IDA resin by using $30 \mathrm{wt} \% \mathrm{H}_{2} \mathrm{O}_{2}$ and $2 \mathrm{M} \mathrm{HNO}_{3}$ as an eluent

\begin{tabular}{|c|c|c|}
\hline \multirow{2}{*}{ Element } & \multicolumn{2}{|c|}{ Recovery, \% } \\
\hline & $30 \mathrm{wt} \% \mathrm{H}_{2} \mathrm{O}_{2}^{\mathrm{a}}$ & $2 \mathrm{M} \mathrm{HNO}_{3}$ \\
\hline Mo(VI) & $94.4 \pm 2.3$ & 92.1 \\
\hline $\mathrm{V}(\mathrm{V})$ & $93.8 \pm 2.2$ & 91.0 \\
\hline $\mathrm{Nb}(\mathrm{V})$ & $80.1 \pm 4.4$ & 82.2 \\
\hline $\mathrm{Ta}(\mathrm{V})$ & $76.8 \pm 3.8$ & 79.3 \\
\hline W(VI) & $66.5 \pm 2.3$ & 62.4 \\
\hline $\mathrm{Zr}(\mathrm{IV})$ & $2.60 \pm 0.04$ & 36.3 \\
\hline $\mathrm{Tl}(\mathrm{I})$ & $2.13 \pm 0.06$ & 32.1 \\
\hline $\mathrm{Ba}(\mathrm{II})$ & $0.88 \pm 0.08$ & 94.8 \\
\hline $\mathrm{Cd}(\mathrm{II})$ & $0.57 \pm 0.55$ & 95.2 \\
\hline $\operatorname{Sr}(\mathrm{II})$ & $0.56 \pm 0.05$ & 94.4 \\
\hline $\mathrm{Yb}(\mathrm{III})$ & $0.53 \pm 0.52$ & 91.4 \\
\hline $\operatorname{Er}(\mathrm{III})$ & $0.48 \pm 0.49$ & 92.5 \\
\hline Dy(III) & $0.44 \pm 0.46$ & 93.0 \\
\hline $\mathrm{Ce}(\mathrm{III})$ & $0.01 \pm 0.00_{2}$ & 94.8 \\
\hline $\operatorname{Pr}(\mathrm{III})$ & $0.00_{4} \pm 0.00_{1}$ & 94.8 \\
\hline $\mathrm{Eu}(\mathrm{III})$ & $0.01 \pm 0.00_{2}$ & 96.2 \\
\hline $\mathrm{Nd}(\mathrm{III})$ & $0.01 \pm 0.00_{003}$ & 95.9 \\
\hline $\mathrm{Sm}(\mathrm{III})$ & $0.01 \pm 0.00_{3}$ & 95.6 \\
\hline $\mathrm{Pb}(\mathrm{II})$ & $0.28 \pm 0.24$ & 82.0 \\
\hline Hf(IV) & $0.20 \pm 0.03$ & 75.5 \\
\hline $\mathrm{Co}(\mathrm{III})$ & $0.15 \pm 0.08$ & 94.8 \\
\hline $\mathrm{Ni}(\mathrm{III})$ & $0.06 \pm 0.03$ & 97.7 \\
\hline $\mathrm{Al}(\mathrm{III})$ & $\mathrm{ADL}^{\mathrm{b}}$ & 42.2 \\
\hline $\mathrm{Fe}(\mathrm{III})$ & $\mathrm{ADL}^{\mathrm{b}}$ & 84.1 \\
\hline $\mathrm{La}(\mathrm{III})$ & $\mathrm{ADL}^{\mathrm{b}}$ & 95.8 \\
\hline $\mathrm{Mn}(\mathrm{II})$ & $\mathrm{ADL}^{\mathrm{b}}$ & 98.0 \\
\hline $\mathrm{Zn}(\mathrm{II})$ & $\mathrm{ADL}^{\mathrm{b}}$ & 99.2 \\
\hline
\end{tabular}

a. Mean \pm standard deviation, $n=3$.

b. The ADL indicates that the concentration in the $\mathrm{H}_{2} \mathrm{O}_{2}$ eluent was less than the instrumental detection limit measured by ICP-AES or ICP-MS.

for $1 \mathrm{~min}$, and filtered by a $0.45-\mu \mathrm{m}$ pore-size disposable membrane filter. The $\mathrm{H}_{2} \mathrm{O}_{2}$ eluent was diluted by 50 -fold with the addition of $0.1 \mathrm{M} \mathrm{HNO}_{3}$. Then, $0.2 \mathrm{~g}$ of a $1 \mathrm{mg} \mathrm{kg}^{-1} \mathrm{Re}$ solution was added to the analytical solution for an internal standard correction in the ICP-MS analysis. The recovery and removal rate were estimated using the following Eqs. (1) and (2), respectively:

$$
\text { Recovery } \%=\left(C_{1} / C_{0}\right) \times 100,
$$

$$
\text { Removal rate } \%=\left(C_{1}-C_{0}\right) / C_{0} \times 100 \text {. }
$$

$C_{0}$ and $C_{1}$ are the amounts $(\mu \mathrm{g})$ of the metal ion contained in the original solution loaded to the IDA resin, and that in the eluted $\mathrm{H}_{2} \mathrm{O}_{2}$ solution, respectively. The recovery and removal rate were used as an index of recovering the target metals $(\mathrm{V}$, Mo and $\mathrm{W}$ ), and of removing the other metals, respectively.

\section{Results and Discussion}

Elution behavior of metal ions adsorbed on the IDA resin by $\mathrm{H}_{2} \mathrm{O}_{2}$

The recoveries of metal ions by using $30 \mathrm{wt} \% \mathrm{H}_{2} \mathrm{O}_{2}$ as the eluent are listed in Table 2, together with those by $2 \mathrm{M} \mathrm{HNO}_{3}$. As can be seen in Table 2, V(V), Mo(VI), W(VI), Nb(V), and $\mathrm{Ta}(\mathrm{V})$ showed higher recoveries than other metal ions in the

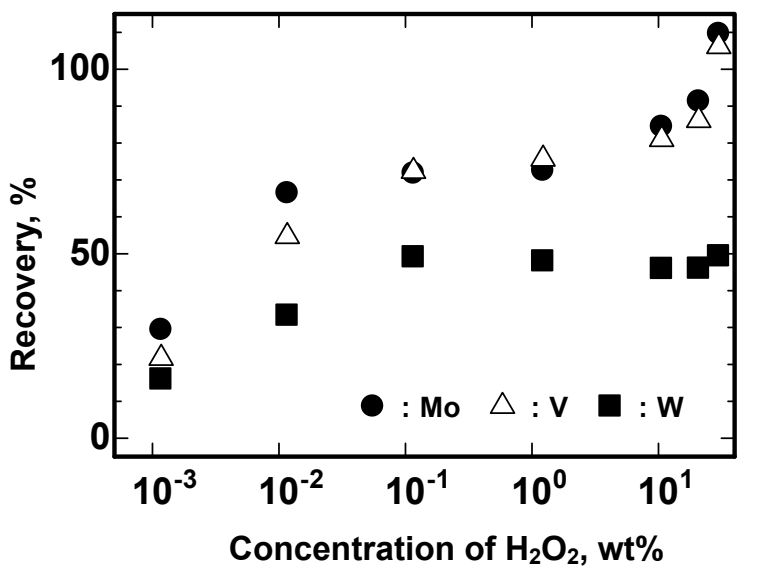

Fig. 1 Dependence of the $\mathrm{H}_{2} \mathrm{O}_{2}$ concentration in the elution process on the recoveries of $\mathrm{V}, \mathrm{Mo}$ and $\mathrm{W}$.

$\mathrm{H}_{2} \mathrm{O}_{2}$ eluting process. Furthermore, the recoveries of $\mathrm{V}(\mathrm{V})$, $\mathrm{Mo}(\mathrm{VI}), \mathrm{W}(\mathrm{VI}), \mathrm{Nb}(\mathrm{V})$, and $\mathrm{Ta}(\mathrm{V})$ by the $\mathrm{H}_{2} \mathrm{O}_{2}$ elution were similar to those by $2 \mathrm{M} \mathrm{HNO}_{3}$ elution, which provided complete elution of the adsorbed metal ions on the IDA resin. ${ }^{11}$ This result means that $\mathrm{V}(\mathrm{V}), \mathrm{Mo}(\mathrm{VI}), \mathrm{W}(\mathrm{VI}), \mathrm{Nb}(\mathrm{V})$, and $\mathrm{Ta}(\mathrm{V})$ adsorbed on the IDA resin could be almost removed by $\mathrm{H}_{2} \mathrm{O}_{2}$ elution. Thus, the dependence of the recoveries of $\mathrm{V}(\mathrm{V})$, $\mathrm{Mo}(\mathrm{VI})$, and $\mathrm{W}(\mathrm{VI})$ on the $\mathrm{H}_{2} \mathrm{O}_{2}$ concentration was examined. The results are shown in Fig. 1. It can be seen in Fig. 1 that the $\mathrm{V}(\mathrm{V}), \mathrm{Mo}(\mathrm{VI})$, and $\mathrm{W}(\mathrm{VI})$ recoveries increased with an increase in the $\mathrm{H}_{2} \mathrm{O}_{2}$ concentration. Since $30 \mathrm{wt} \% \mathrm{H}_{2} \mathrm{O}_{2}$ is the highest concentration in commercially available $\mathrm{H}_{2} \mathrm{O}_{2}$, we used it for experiments of $\mathrm{H}_{2} \mathrm{O}_{2}$ elution after this.

Subsequent elution by using $2 \mathrm{M} \mathrm{HNO}_{3}$ after $30 \mathrm{wt} \% \mathrm{H}_{2} \mathrm{O}_{2}$ elution was tested. The recoveries of the metal ions by $\mathrm{H}_{2} \mathrm{O}_{2}$ elution and a $2 \mathrm{M} \mathrm{HNO}_{3}$ subsequent elution are shown in Fig. 2, together with those by $2 \mathrm{M} \mathrm{HNO}_{3}$ single elution. As a result, the trend of the recoveries by $2 \mathrm{M} \mathrm{HNO}_{3}$ subsequent elution was complementary observed against those by $\mathrm{H}_{2} \mathrm{O}_{2}$ elution. In fact, the summation of the recoveries by $\mathrm{H}_{2} \mathrm{O}_{2}$ elution and subsequent $\mathrm{HNO}_{3}$ elution was quite similar to those of $2 \mathrm{M}$ single $\mathrm{HNO}_{3}$ elution. This result indicates that $\mathrm{H}_{2} \mathrm{O}_{2}$ elution did not affect the adsorption status of these metal ions, except for $\mathrm{V}(\mathrm{V}), \mathrm{Mo}(\mathrm{VI})$, $\mathrm{W}(\mathrm{VI}), \mathrm{Nb}(\mathrm{V})$, and $\mathrm{Ta}(\mathrm{V})$.

Investigation of the elution mechanisms of $V(V), M o(V I)$, and $W(V I)$ ion by the $\mathrm{H}_{2} \mathrm{O}_{2}$ treatment

It is widely known that $\mathrm{H}_{2} \mathrm{O}_{2}$ is a redox-active reagent, and has both redox functions, as a reductant and an oxidizer. The oxidation state of metal ions strongly affects the formations and stabilities of complexes. Thus, the oxidation numbers of $\mathrm{V}, \mathrm{Mo}$, and $\mathrm{W}$ in the $\mathrm{H}_{2} \mathrm{O}_{2}$ eluent were checked by XPS analysis. Accordingly, the $\mathrm{X}$-ray energies of the $\mathrm{V}, \mathrm{Mo}$, and $\mathrm{W}$ in the $\mathrm{H}_{2} \mathrm{O}_{2}$ eluent were 517.4, 232.5, and $35.4 \mathrm{eV}$, which could be identified as $2 \mathrm{p}_{3 / 2}$ vanadate, $3 \mathrm{~d}_{5 / 2}$ molybdate, and $4 \mathrm{f}_{7 / 2}$ tungstate by the NIST XPS database, respectively. ${ }^{12}$ That is, the oxidation states of $\mathrm{V}, \mathrm{Mo}$, and $\mathrm{W}$ in the $\mathrm{H}_{2} \mathrm{O}_{2}$ eluent were confirmed to be $\mathrm{V}(\mathrm{V}), \mathrm{Mo}(\mathrm{VI})$, and $\mathrm{W}(\mathrm{VI})$, respectively. The oxidation states did not change throughout the treatment process. In other words, no redox reactions occurred in the $\mathrm{H}_{2} \mathrm{O}_{2}$ elution.

Early transition-element ions in their highest oxidation state ( $d^{0}$ electron configuration) can be functioned as Lewis acids toward hydrogen peroxide. ${ }^{13}$ Thus, the UV-vis absorption spectra and IR spectra of $\mathrm{V}(\mathrm{V}), \mathrm{Mo}(\mathrm{VI})$ and $\mathrm{W}(\mathrm{VI})$ ions before and after $\mathrm{H}_{2} \mathrm{O}_{2}$ elution were investigated in order to track the 

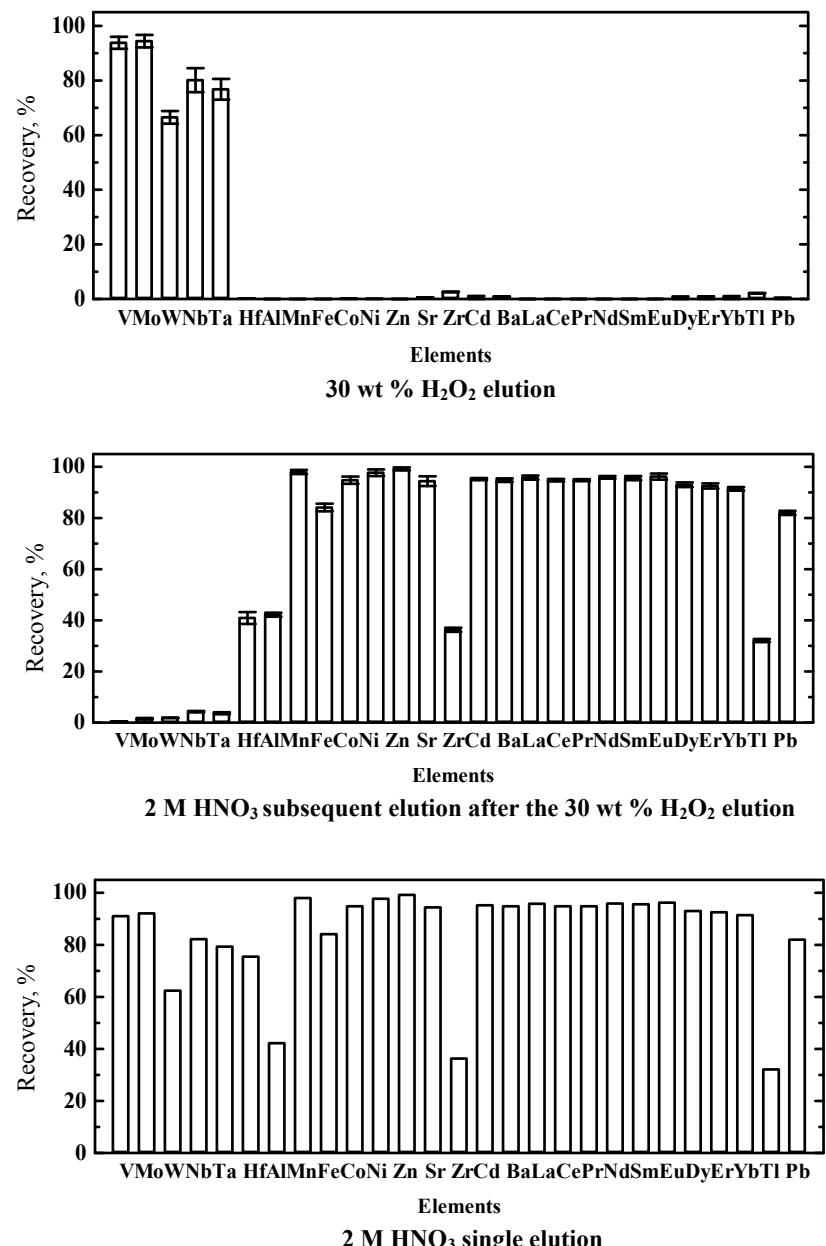

Fig. 2 Recoveries of metal ions obtained by $30 \mathrm{wt} \% \mathrm{H}_{2} \mathrm{O}_{2}$ elution (upper), $2 \mathrm{M} \mathrm{HNO}_{3}$ subsequent elution after the $30 \mathrm{wt} \% \mathrm{H}_{2} \mathrm{O}_{2}$ elution (middle) and $2 \mathrm{M} \mathrm{HNO}_{3}$ single elution (lower). The error bar was estimated as the standard deviation of the recovery in 3-times replicate experiments.

coordination process of peroxo ligands. The UV-vis absorption spectra are shown in Fig. 3. The adsorption peaks of $\mathrm{V}(\mathrm{V})$, $\mathrm{Mo}(\mathrm{VI})$ and $\mathrm{W}(\mathrm{VI})$ ions in the $\mathrm{H}_{2} \mathrm{O}_{2}$ eluent were shifted to higher wavelength number. The adsorption peaks of $\mathrm{V}$, Mo and W in the $\mathrm{H}_{2} \mathrm{O}_{2}$ eluent were 326, 309, and $242 \mathrm{~nm}$, respectively, and similar to those of peroxo-complexes. ${ }^{14,15}$ Furthermore, the IR spectra of $\mathrm{V}(\mathrm{V}), \mathrm{Mo}(\mathrm{VI})$ and $\mathrm{W}(\mathrm{VI})$ in the $\mathrm{H}_{2} \mathrm{O}_{2}$ eluent are shown in Fig. 4. The IR spectra of the $\mathrm{H}_{2} \mathrm{O}_{2}$ eluent show a peak at around $920 \mathrm{~cm}^{-1}$ for $\mathrm{V}(\mathrm{V})$, a narrow peak at $900 \mathrm{~cm}^{-1}$ and a broad peak between 800 and $880 \mathrm{~cm}^{-1}$ for $\mathrm{Mo}(\mathrm{VI})$, and two peaks at $830-850$ and $920-925 \mathrm{~cm}^{-1}$ for $\mathrm{W}(\mathrm{VI})$. Reynolds and Butler have reported that the wavenumbers of the $\mathrm{O}-\mathrm{O}$ stretching of the peroxo-complexes were observed in $900-920$ and $875-900 \mathrm{~cm}^{-1}$ for $\mathrm{V}(\mathrm{V}), 900$ and $865-875 \mathrm{~cm}^{-1}$ for Mo(VI), and $835 \mathrm{~cm}^{-1}$ for $\mathrm{W}(\mathrm{VI})$, respectively. ${ }^{14}$ The present $\mathrm{UV}$ and IR studies suggest the formation of peroxo-complexes through the $\mathrm{H}_{2} \mathrm{O}_{2}$ elution process. Peroxo-complexes of $\mathrm{V}(\mathrm{V})$, $\mathrm{Mo}(\mathrm{VI})$ and $\mathrm{W}(\mathrm{VI})$ are highly stable, due to the coordination of two peroxide groups in the equatorial plane. ${ }^{16}$ In addition, Funahashi et al. have reported that the substitution of the peroxoligand to $\mathrm{VO}_{4}{ }^{2-}$ and $\mathrm{MoO}_{4}^{--}$ions is very labile. ${ }^{17}$ In such a neutral $\mathrm{pH}$ range shown in the $30 \mathrm{wt} \% \mathrm{H}_{2} \mathrm{O}_{2}$ solution $(30 \mathrm{wt} \%$ $\mathrm{H}_{2} \mathrm{O}_{2}$ solution shows $c a$. $\mathrm{pH}$ 7), mono- and diperoxo-species become predominated species. ${ }^{18,19} \mathrm{Mo}(\mathrm{VI})$ and $\mathrm{W}(\mathrm{VI})$ ions
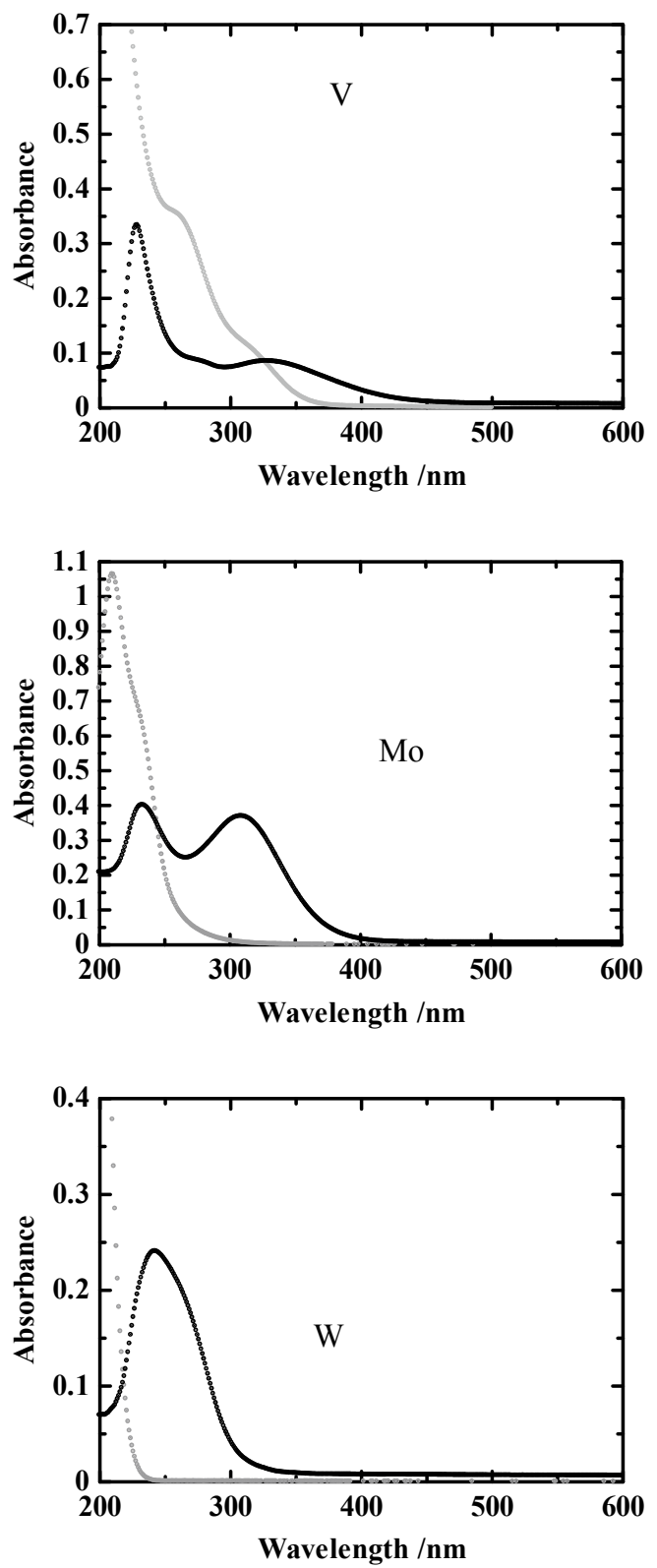

Fig. 3 UV-vis absorption spectra observed in the original solution and the $\mathrm{H}_{2} \mathrm{O}_{2}$ eluent. The gray and black lines indicate the UV-vis absorption spectrum of each metal in the original solution and the $\mathrm{H}_{2} \mathrm{O}_{2}$ eluting solution, respectively. The condition of the $\mathrm{H}_{2} \mathrm{O}_{2}$ elution is mentioned in the Experimental section. The $\mathrm{H}_{2} \mathrm{O}_{2}$ concentration was set at $0.1 \mathrm{wt} \%$. The original $\mathrm{V}, \mathrm{Mo}$, and $\mathrm{W}$ solutions were prepared by dissolving $\mathrm{NH}_{4} \mathrm{VO}_{3}$, $\left(\mathrm{NH}_{4}\right)_{6} \mathrm{Mo}_{7} \mathrm{O}_{24} \cdot 4 \mathrm{H}_{2} \mathrm{O}$, and $\mathrm{Na}_{2} \mathrm{WO}_{4}$ into pure water, respectively.

form a 1:1 octahedral complex $\left(\left[\mathrm{MO}_{3}(\mathrm{IDA})\right]^{2-},(\mathrm{M}: \mathrm{Mo}(\mathrm{VI})\right.$ or $\mathrm{W}(\mathrm{VI})$ ), where a nitrogen and two proton-dissociated carboxylic acids of IDA coordinate the metal core, with the IDA functional group in a weak acidic and neutral $\mathrm{pH}$ range. ${ }^{20}$ It is expected that substitution of the peroxide ligand causes a depression of the stability of the metal-IDA complex as a side reaction. Furthermore, the adsorption capacities of the V(V), Mo(VI) and $\mathrm{W}(\mathrm{VI})$ ions to the IDA ligands in both the neutral and basic $\mathrm{pH}$ range are remarkably weaker than those in the acidic $\mathrm{pH}$ range. ${ }^{20,21}$ Depression of the adsorption capacity may be caused by electrostatic repulsion between the oxo (peroxo)-anions and the dissociated carboxylic acid groups in IDA. In fact, 


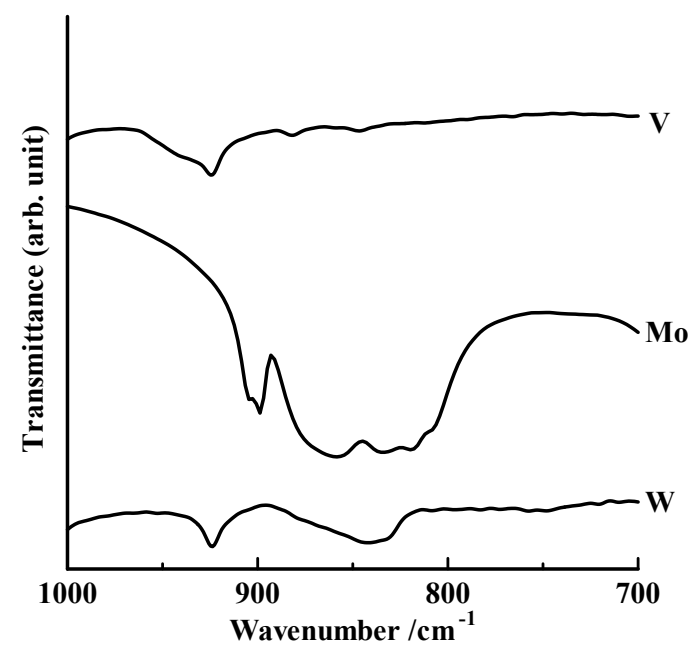

Fig. 4 Infrared spectra observed in the $\mathrm{H}_{2} \mathrm{O}_{2}$ eluent. The $\mathrm{H}_{2} \mathrm{O}_{2}$ eluents were freeze-dried, and then the residues were mixed with $\mathrm{KBr}$. $\mathrm{The} \mathrm{KBr}$ pellets were used for IR analysis.

the predominant species of the oxoanion are shifted from $\mathrm{H}_{2} \mathrm{VO}_{4}$ to $\mathrm{HVO}_{4}{ }^{2-}$ for $\mathrm{V}(\mathrm{V})$, from $\mathrm{HMoO}_{4}^{--}$to $\mathrm{MoO}_{4}{ }^{2-}$ for $\mathrm{Mo}(\mathrm{VI})$, and from $\mathrm{HWO}_{4}{ }^{-}$to $\mathrm{WO}_{4}{ }^{2-}$ for $\mathrm{W}(\mathrm{VI})$, also, the anionic properties increase toward the high $\mathrm{pH}$ region. ${ }^{22}$ In conclusion, the desorption of these metal ions from IDA functional groups was generated by destabilization along with coordination of the peroxo-ligands to the $\mathrm{V}(\mathrm{V}), \mathrm{Mo}(\mathrm{VI})$ and $\mathrm{W}(\mathrm{VI})$-IDA complex, and a decrease in the adsorption capacity by the electrostatic repulsion between IDA and oxoanions generated in the neutral $\mathrm{pH}$ range.

Separation of $V$, Mo, and $W$ in an acid soluble fraction of incineration fly-ash of waste

The method was applied to the separation of V, Mo, and W in an acid soluble fraction of fly-ash. The recoveries of V, Mo, W and the removal rates of major metals are summarized in Table 3. The recoveries of $\mathrm{V}$, Mo, and $\mathrm{W}$ were 83.4, 88.1, and $69.3 \%$, respectively. The relative standard deviations of the recoveries of $\mathrm{V}$, Mo and $\mathrm{W}$ were less than $10 \%$. The concentrations of almost all major elements in the acid soluble fraction were less than the instrumental detection limits, measured by ICP-AES or ICP-MS. The removal rates of all of these elements were higher than $92 \%$.

\section{Conclusions}

Consequently, the $\mathrm{H}_{2} \mathrm{O}_{2}$ elution and the subsequent elution of $\mathrm{HNO}_{3}$ to the IDA resin allows metal ions to be separated into three groups. Alkaline and alkaline earth elements ions are firstly separated from other multivalent metal ions in the adsorption to IDA resin because of their very low chelating ability. Secondly, V(V), Mo(VI), W(VI), $\mathrm{Nb}(\mathrm{V})$, and $\mathrm{Ta}(\mathrm{V})$ can be separated by $\mathrm{H}_{2} \mathrm{O}_{2}$ elution from other multivalent metal ions adsorbed on the IDA resin. Finally, the remaining metal ions adsorbed on the IDA resin can be subsequently eluted by a $\mathrm{HNO}_{3}$ solution.

A highly selective separation of oxoanion-forming elements, such as $\mathrm{V}, \mathrm{Mo}, \mathrm{W}, \mathrm{Nb}$, and Ta, from over 20 elements adsorbed IDA resin by using $\mathrm{H}_{2} \mathrm{O}_{2}$ was established. Especially, V, Mo, and $\mathrm{W}$ are designated as stockpiled mineral species by the
Table 3 Recoveries and removal rates of metal ions from the acid soluble fraction of fly-ash with the IDA resin adsorption/ $\mathrm{H}_{2} \mathrm{O}_{2}$ elution method

\begin{tabular}{|c|c|c|c|c|}
\hline Element & Spike/ $\mu \mathrm{g}$ & Found $/ \mu \mathrm{g}$ & Recovery, $\%^{\mathrm{a}}$ & $\mathrm{RSD}^{\mathrm{b}}$ \\
\hline $\mathrm{V}(\mathrm{V})$ & 160 & 133 & $83.4 \pm 2.5$ & 3.0 \\
\hline Mo(VI) & 53.3 & 48.5 & $88.1 \pm 3.3$ & 3.7 \\
\hline \multirow[t]{2}{*}{$\mathrm{W}(\mathrm{VI})$} & 52.6 & 36.5 & $69.3 \pm 5.4$ & 7.8 \\
\hline & Before $/ \mu \mathrm{g}$ & After treatment $/ \mu \mathrm{g}$ & \multicolumn{2}{|c|}{ Removal rate, $\%^{\mathrm{a}}$} \\
\hline $\mathrm{Ca}$ & 23100 & 4.48 & \multicolumn{2}{|c|}{$>99.9$} \\
\hline $\mathrm{Na}$ & 4912 & 106 & \multicolumn{2}{|c|}{97.8} \\
\hline $\mathrm{Mg}$ & 1663 & $\mathrm{ADL}^{\mathrm{c}}$ & \multicolumn{2}{|c|}{99.7} \\
\hline $\mathrm{Al}$ & 5041 & $\mathrm{ADL}^{\mathrm{c}}$ & \multicolumn{2}{|c|}{99.8} \\
\hline $\mathrm{Fe}$ & 2301 & $\mathrm{ADL}^{\mathrm{c}}$ & \multicolumn{2}{|c|}{$>99.9$} \\
\hline $\mathrm{Zn}$ & 142 & $\mathrm{ADL}^{\mathrm{c}}$ & \multicolumn{2}{|c|}{99.9} \\
\hline $\mathrm{Mn}$ & 52.2 & $\mathrm{ADL}^{\mathrm{c}}$ & \multicolumn{2}{|c|}{99.6} \\
\hline $\mathrm{Pb}$ & 47.0 & $\mathrm{ADL}^{\mathrm{c}}$ & \multicolumn{2}{|c|}{92.4} \\
\hline $\mathrm{Cu}$ & 27.6 & $\mathrm{ADL}^{\mathrm{c}}$ & \multicolumn{2}{|c|}{98.1} \\
\hline $\mathrm{Ni}$ & 13.6 & $\mathrm{ADL}^{\mathrm{c}}$ & \multicolumn{2}{|c|}{99.8} \\
\hline $\mathrm{Ga}$ & 2.17 & $\mathrm{ADL}^{\mathrm{c}}$ & \multicolumn{2}{|c|}{$>99.9$} \\
\hline Co & 1.16 & $\mathrm{ADL}^{\mathrm{c}}$ & \multicolumn{2}{|c|}{99.3} \\
\hline In & 0.03 & $\mathrm{ADL}^{\mathrm{c}}$ & \multicolumn{2}{|c|}{97.3} \\
\hline
\end{tabular}

a. Mean \pm standard deviation, $n=3$.

b. Relative standard deviation, $\%$.

c. ADL indicates that the concentration in the $\mathrm{H}_{2} \mathrm{O}_{2}$ eluent after the treatment was less than the instrumental detection limit measured by ICP-AES or ICP-MS.

Japanese Government. ${ }^{23}$ Since this method provides a selective separation of these elements from many elements in a one-step process, this will be a useful method for recycling them from industrial wastes.

\section{Acknowledgements}

This work was supported, in part, by a KAKENHI (22656207) grant from Japan Society for the Promotion of Science. This work was also supported by a grant from the University of Tokushima.

\section{References}

1. Y. Zhu, A. Itoh, E. Fujimori, T. Umemura, and $\mathrm{H}$. Haraguchi, Bull. Chem. Soc. Jpn., 2005, 78, 659.

2. E. P. Oliveira, L. Yang, R. E. Sturgeon, R. E. Santelli, M. A. Bezerra, S. N. Willie, and R. Capilla, J. Anal. At. Spectrom., 2011, 26, 578 .

3. C. R. Adhikari, D. Parajuli, H. Kawakita, R. Chand, K. Inoue, and K. Ohto, Chem. Lett., 2007, 36, 1254.

4. T. Inui, K. Fujita, M. Kitano, and T. Nakamura, Anal. Sci., 2010, 26, 1093.

5. T. Yabutani, K. Chiba, and H. Haraguchi, Bull. Chem. Soc. Jpn., 2001, 74, 31.

6. T. Yabutani, S. Ji, F. Mouri, H. Sawatari, A. Itoh, K. Chiba, and H. Haraguchi, Bull. Chem. Soc. Jpn., 1999, 72, 2253.

7. Y. Kon, H. Hachiya, Y. Ono, T. Matsumoto, and K. Sato, Synthesis, 2011, 7, 1092.

8. T. Chishiro, Y. Kon, and K. Sato, Yuki Gosei Kagaku Kyokaishi, 2008, 66, 1085.

9. J. A. Connor and E. A. V. Ebsworth, Advances in Inorganic Chemistry and Radiochemistry, 1964, 6, 279. 
10. M. Tamaru, T. Yabutani, and J. Motonaka, Bunseki Kagaku, 2004, 53, 1435.

11. C. J. Cheng, T. Akagi, and H. Haraguchi, Anal. Chim. Acta, 1987, 198, 173.

12. NIST X-ray Photoelectron Spectroscopy Database, NIST Standard Reference Database 20, Ver. 3.5, prepared by National Institute of Standard and Technology (NIST, USA), http://srdata.nist.gov/xps/Default.aspx.

13. R. A. Sheldon and J. K. Kochi, "Metal-Catalyzed Oxidation of Organic Compounds", Academic, New York, 1981, 71.

14. M. S. Reynolds and A. Butler, Inorg. Chem., 1996, 35, 2378.

15. S. U. Kreingol'd and A. N. Vasnev, Russ. J. Inorg. Chem., 1980, 25, 1355.

16. T.-J. Won, B. M. Sudam, and R. C. Thompson, Inorg. Chem., 1994, 33, 3804.
17. S. Funahashi, Y. Ito, and M. Tanaka, J. Coord. Chem., 1973, 3, 125.

18. P. Lage, A. Ingegard, and G. Andras, Coord. Chem. Rev., 2003, 237, 77.

19. L. M. Schwane and R. C. Thompson, Inorg. Chem., 1989, 28,3938 .

20. M. H. H. Mahmoud, M. Kanesato, T. Yokoyama, and T. M. Suzuki, Anal. Sci., 1984, 10, 929.

21. T. Soldi, M. Pesavento, and G. Alberti, Anal. Chim. Acta, 1996, 323, 27.

22. D. R. Turner, M. Whitfield, and A. G. Dickson, Geochim. Cosmochim. Acta, 1981, 45, 855.

23. JOGMEC Activities, Japan Oil, Gas and Metals National Corporation (JOGMEC), http://www.jogmec.go.jp/english/ activities/stockpiling_metal/raremetals.html. 